\title{
Pendampingan Program Pilah Sampah Di Kelompok Pengelola Sampah Ngudi Resik Desa Potorono, Banguntapan, Bantul
}

\author{
Aris Slamet Widodo1, Adhianty Nurjanah ${ }^{2}$ \\ 1 Prodi Agribisnis, Universitas Muhammadiyah Yogyakarta1 \\ 2 Prodi Komunikasi, Universitas Muhammadiyah Yogyakarta2 \\ armando1215sw@gmail.com \\ DOI: $10.18196 / p p m .36 .323$
}

\begin{abstract}
Abstrak
Tujuan pengabdian di Pedukuhan Banjardadap, Desa Potorono, Kecamatan Banguntapan, Kabupaten Bantul adalah melakukan pemberdayaan masyarakat agar terjadi perubahan kesadaran serta perilaku masyarakat dalam pengelolaan sampah rumah tangga. Kelembagaan masyarakat pengelola sampah yaitu Ngudi Resik Barokah merupakan kelompok sasaran utama pendampingan ini. Metode yang digunakan adalah menggunakan pendekatan PRA (participatory rural appraisal) dengan teknik FGD (focus group discussion). Kegiatan yang dilaksanakan adalah penyuluhan, pelatihan, dan pendampingan. Hasil kegiatan menunjukan meningkatnya komitmen dan terjadi perubahan sikap terhadap pentingnya pengelolaan sampah. Meningkatnya kemampuan pengurus dalam pengelolaan sampah organik rumah tangga dan teknik pemilahan sampah (3R). Terbentuknya inisiasi lembaga Pilah Sampah di Pedukuhan Banjardadap. Berdasarkan hasil pengabdian menunjukan bahwa target dari pengabdian telah tercapai yaitu meningkatnya kesadaran warga terkait pentingnya pengelolaan sampah sehingga terjadi perubahan perilaku masyarakat dalam pengelolaan sampah serta penguatan kelembagaan Pilah Sampah.
\end{abstract}

Kata Kunci: Pemberdayaan, lembaga, pilah, sampah

\section{Pendahuluan}

Desa Potorono merupakan salah satu desa yang berada di Kecamatan Banguntapan, Kabupaten Bantul, Daerah Istimewa Yogyakarta. Desa Potorono memiliki luas 435,46 Ha. Desa Potorono memiliki sembilan pedukuhan diantaranya Pedukuhan Potorono, Prangwedanan, Salakan, Condrowangsan, Nglaren, Mertosanan Wetan, Mertosanan Kulon, Balong Lor, dan Banjardadap. Wilayah Desa Potorono merupakan daerah dataran rendah yang sebagian besar penduduknya bermata pencaharian buruh swasta, petani, buruh harian lepas, dan lainnya. Pedukuhan Banjardadap merupakan pedukuhan yang berada di Desa Potorono, Kecamatan Banguntapan, Kabupaten Bantul, Daerah Istimewa Yogyakarta. Pedukuhan Banjardadap memiliki 8 RT. Penduduk di Pedukuhan Banjardadap sebagian besar menganut agama Islam. Kondisi sosial warga di Pedukuhan Banjardadap termasuk sudah aktif dengan adanya kegiatan rutin yang biasa dilakukan oleh orang tua maupun pemuda. Kegiatan tersebut antara lain kegiatan RT, seperti gotong royong setiap minggu, kegiatan PPK serta Dasawisma dan lain sebagainya.

Sebagian besar warga Padukuhan Banjardadap belum melakukan pengelolaan sampah. Akan tetapi sebagian besar penduduk membuang sampah di lubang kemudian dibakar, bahkan ada beberapa warga yang membuang sampah di sungai dan jalan petak sawah. Disisi lain, kondisi perekonomian masyarakat yang rata-rata sebagai petani dan buruh memiliki pendapatan yang tidak terlalu tinggi atau hanya sebatas Upah Minimum Kabupaten. Secara umum bahwa pendapatan masyarakat rendah dibandingkan dengan kebutuhan hidup sehari-hari. Selain memiliki tingkat pendapatan yang rendah, masyarakat sebenarnya memiliki potensi sosial yang besar yaitu kerukunan, empati dan semangat gotong royong. Hal tersebut menjadi modal sosial yang tinggi dan mampu meringankan beban hidup masyarakat. Keberadaan masjid dan fasilitas umum menjadikan kehidupan sosial berjalan dengan baik.

Pada awal tahun 2019 masyarakat Pedukuhan Banjardadap sudah sadar akan kebersihan lingkugan yaitu dengan diadakannya program pilah sampah. Program tersebut dijalankan oleh 
sebagian pemuda-pemudi Padukuhan Banjardadap. Pilah sampah dilakukan di setiap rumah warga dan kemudian diambil oleh pengurus yaitu pemuda-pemudi yang nantinya akan dikumpulkan dan dijual kepada agen rongsok di pedukuhan tersebut. Namun, setelah program pilah sampah berjalan beberapa kali, program tersebut vakum atau sudah tidak lagi berjalan. Hal tersebut dikarenakan rendahnya minat pengurus akan program pilah sampah, di mana pengurus memiliki persepsi akan rendahnya hasil yang didapat dari program pilah sampah. Di samping itu, belum semua masyarakat memahami arti penting pengelolaan sampah bagi keberlangsungan kebersihan dan keindahan lingkungan yang akan berdampak pada kesehatan lingkungan.

Padahal pada pertengahan tahun 2019 Pedukuhan Banjardadap memperoleh bantuan dana aspirasi dari Dewan Perwakilan Rakyat (DPR) dan dana APBD T.A. 2019 dari Dinas Lingkungan Hidup (DLH) yaitu berupa sarana prasarana seperti rumah pilah sampah, kendaraan angkut beroda tiga, gerobak, mesin pencacah oraganik, dan tempat sampah, serta warga juga memperoleh sosialisasi dan pelatihan pengelolaan sampah. Namun sarana prasaran tersebut belum pernah digunakan sebagai mana semestinya, dikarenakan program pilah sampah yang sudah tidak lagi berjalan dan tidak adanya kelompok pengurus program pilah sampah.

Berdasarkan potensi sumberdaya dan permasalahan yang ada maka program yang dilaksanakan adalah "Pendampingan Pilah Sampah Mandiri di Kelompok Pengelola Sampah Ngudi Resik" dan tujuan pendampingan tersebut adalah:

a. Meningkatkan kesadaran masyarakat akan pentingnya pengelolaan sampah dalam kesehatan lingkungan.

b. Meningkatkan pengetahuan dan keterampilan masyarakat dalam pengelolaan sampah 3R (Reduce, Reuse, and Recycle).

c. Inisiasi penguatan kelembagaan/organisasi yang berinduk di rumah pilah sampah.

d. Perubahan perilaku masyarakat dalam pengelolaan sampah.

\section{Metode Pemberdayaan}

Secara umum metoda dasar yang digunakan adalah metode Participatory Rural Appraisal (PRA), yang didalamnya melingkupi kegiatan: Pelatihan, Pendampingan, Focus Group Discussion (FGD) dan Workshop. Adanya pandemi COVID-19 mengharuskan setiap kegiatan dilaksanakan dengan protokol COVID-19, atupun kegiatan pendampingan secara online dengan tujuan mengantisipasi penyebaran virus COVID-19. Rincian tahapan pelaksanaan dapat dilihat pada table dibawah ini.

\begin{tabular}{|c|c|c|}
\hline Tahapan & Kegiatan & Teknologi/Metode \\
\hline Sosialisasi & $\begin{array}{ll}- & \text { Pembentukan Tim } \\
\text { - } & \text { Observasi dan Transfer Informasi } \\
& \text { Program } \\
\text { - } & \text { Penyuluhan }\end{array}$ & $\begin{array}{ll}- & \text { Observasi \& FGD } \\
\text { Penyuluhan tentang pentingnya pengelolaan } \\
\text { sampah terhadap lingkungan }\end{array}$ \\
\hline Masuk Komunitas & $\begin{array}{ll}- & \text { Proses masuk ke komunitas } \\
\text { - } & \text { Membangun hubungan } \\
\text { - } & \text { Toktry Point Issue } \\
& \text { Tokoh-tokoh kunci pendukung } \\
\text { dan penghambat }\end{array}$ & • $\quad$ FGD \\
\hline Open Issue & $\begin{array}{ll}- & \text { Pengkajian situasi dan kondisi } \\
\text { - } & \text { Menentukan kegiatan teknik }\end{array}$ & $\begin{array}{ll}- & \text { Observasi } \\
- & \text { Wawancara } \\
- & \text { FGD } \\
- & \text { Narasumber }\end{array}$ \\
\hline $\begin{array}{l}\text { Pemberdayaan } \\
\text { Masyarakat (teknis } \\
\text { transfer teknologi) }\end{array}$ & $\begin{array}{ll}- & \text { Pelatihan } \\
- & \text { Pendampingan } \\
- & \text { Workshop }\end{array}$ & $\begin{array}{ll}- & \text { FGD } \\
\text { - } & \text { Pelatihan Motivasi } \\
\text { Pelatihan teknis keterampilan pengelolaan } \\
\text { sampah (pilah sampah dan pengolahan } \\
\text { sampah organik) }\end{array}$ \\
\hline $\begin{array}{l}\text { Pengkaderan, } \\
\text { Membangun Dukungan, } \\
\text { dan Penguatan } \\
\text { Kelembagaan }\end{array}$ & $\begin{array}{ll} & \text { Pengkaderan dan pelibatan peran } \\
\text { - } & \text { Penguatan kelembagaan }\end{array}$ & $\begin{array}{ll}- & \text { FGD } \\
\text { - } & \text { Penguatan kelembagaan masyarakat peduli } \\
& \text { sampah (pilah sampah) }\end{array}$ \\
\hline Phasing Out & $\begin{array}{ll} & \text { Monitoring dan Evaluasi }\end{array}$ & $\begin{array}{ll}\bullet & \text { FGD Aturan Bersama } \\
- & \text { FGD Tim Monitoring }\end{array}$ \\
\hline
\end{tabular}




\section{Pelaksanaan dan Pembahasan}

\section{A.Profil Kelompok Sasaran}

Desa Potorono merupakan salah satu desa yang berada di Kecamatan Banguntapan, Kabupaten Bantul, Daerah Istimewa Yogyakarta. Desa Potorono memiliki luas 435,46 Ha. Desa Potorono memiliki sembilan pedukuhan diantaranya Pedukuhan Potorono, Prangwedanan, Salakan, Condrowangsan, Nglaren, Mertosanan Wetan, Mertosanan Kulon, Balong Lor, dan Banjardadap. Wilayah Desa Potorono merupakan daerah dataran rendah yang sebagian besar penduduknya bermata pencaharian buruh swasta, petani, buruh harian lepas, dan lainnya. Pedukuhan Banjardadap merupakan pedukuhan yang berada di Desa Potorono, Kecamatan Banguntapan, Kabupaten Bantul, Daerah Istimewa Yogyakarta. Pedukuhan Banjardadap memiliki 8 RT. Penduduk di Pedukuhan Banjardadap sebagian besar menganut agama Islam. Kondisi sosial warga di Pedukuhan Banjardadap termasuk sudah aktif dengan adanya kegiatan rutin yang biasa dilakukan oleh orang tua maupun pemuda. Kegiatan tersebut antara lain kegiatan RT, seperti gotong royong setiap minggu, kegiatan PPK serta Dasawisma dan lain sebagainya.

Aspek kelembagaan merupakan sebuah komponen penting dalam suatu wilayah, disamping itu mempunyai fungsi ataupun peranan sebagai agen sosialisasi perubahan terencana yang tumbuh dari masyarakat dan atau diprakarsai oleh pemerintah terkait. Kelembagaan di Dusun Banjardadap yang mempunyai peran dalam pengelolaan sampah rumah tangga adalah kelembagaan Rumah Pilah Sampah yang bernama "Ngudi Resik Barokah". Namun, kelembagaan RPS tersebut belum berjalan sebagaimana mestinya, yaitu kurangnya koordinasi dan kurangnya keaktifan kader lembaga.

\section{B. Pelaksanaan Pemberdayaan}

1) Silaturahmi, observasi, dan motivasi dengan tokoh masyarakat serta kader lembaga RPS Dusun Banjardadap. Kegiatan silaturahmi, observasi, dan motivasi dikukan pada 11 Maret 2020. Pada kegiatan ini disampaikan bahwa tim pengabdian akan melakukan pendampingan selama 3 bulan kedepan terkait pengelolaan sampah. Kemudian melihat situasi, kondisi, dan potensi Dusun Banjardadap yang berkaitan dengan kesehatan lingungan serta pengelolaan sampah. Pemberian motivasi kepada tokoh masyarakat dan kader lembaga RPS adalah dengan mengingatkan pentinganya pengelolaan sampah dalam menunjang terwujudnya lingkungan bersih, indah dan nyaman, serta kebiasaan hidup sehat.

2) Kunjungan ke Rumah Pilah Sampah untuk pendampingan awal. Kegiatan kunjungan ke Rumah Pilah Sampah ini dilakukan pada 19 Juni 2020. Hal ini dikarenakan selama masa pandemi masyarakat membatasi akses keluar masuk dusun, sehingga kegiatan pendampingan harus diundur selama 3 bulan. Setelah dilakukan kunjungan diketahui bahwa kondisi lembaga Rumah Pilah Sampah vakum bahkan sudah tidak berjalan lagi. Di mana kelembagaan pilah sampah sebelumnya dimotori oleh Karang Taruna dusun. 


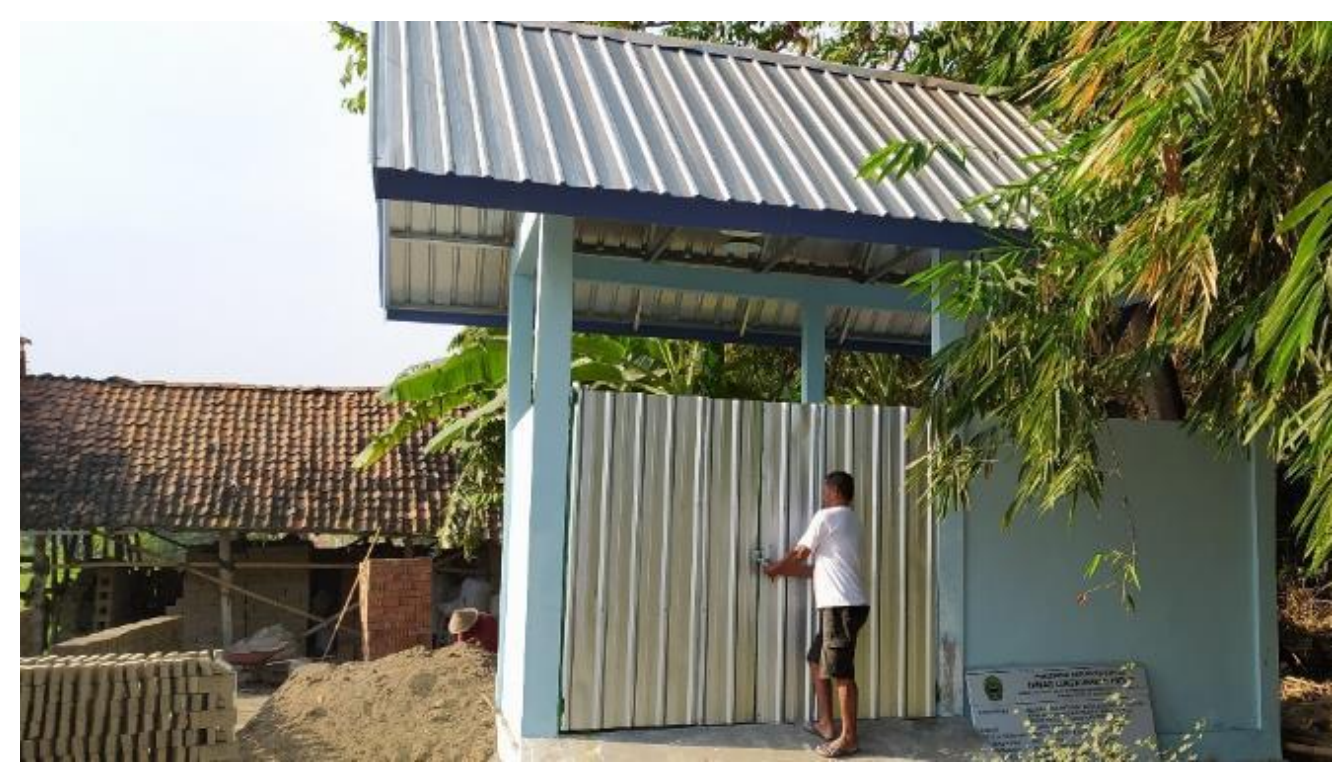

Gambar 1. Rumah Pilah Sampah Ngudi Resik Barokah

3) Pendampingan untuk inisiasi penguatan kelembagaan Rumah Pilah Sampah. Kegiatan pendampingan inisiasi penguatan kelembagaan Rumah Pilah Sampah dilakukan pada 15 Juli 2020. Kelembagaan merupakan faktor penting dalam menggerakan motivasi dan kesadaran masyarakat untuk melakukan pengelolaan sampah. Setelah kunjungan diketahui munculnya minat masyarakat untuk melakukan program pilah sampah, yang diawali dengan rencana pembentukan kelembagaan bekerjasama dengan ibu-ibu PKK.

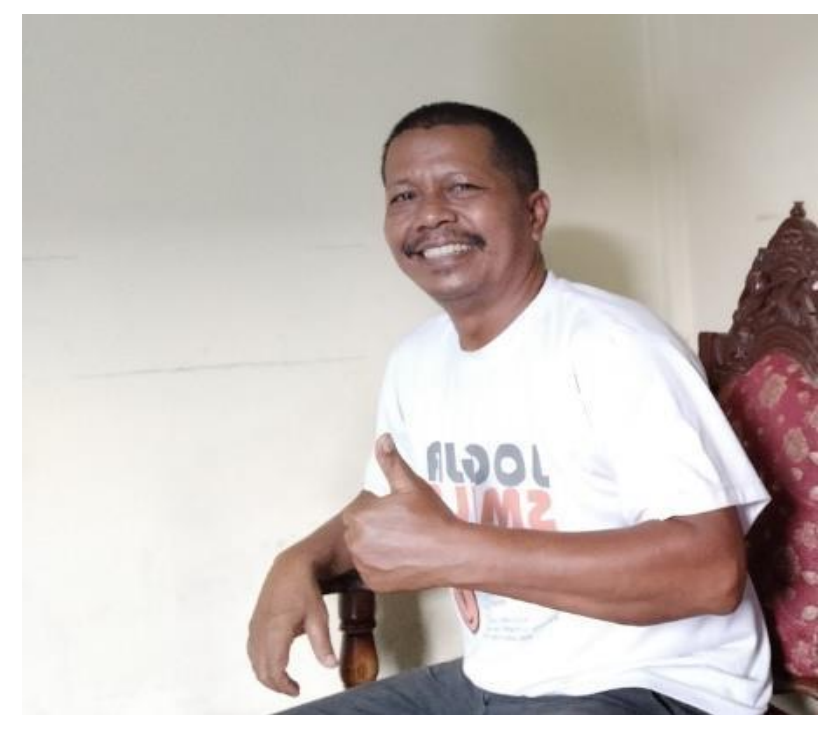

Gambar 2. Pendampingan inisiasi penguatan kelembagaan

4) Pelatihan dan Workshop terkait pengelolaan sampah dilakukan di Dusun Jejeran 1, Desa Wonokromo, Kecamatan Pleret. Kegiatan tersebut dilaksanakan pada tanggal 29 Juli 2020. Pelatihan dan Workshop dihadiri oleh Trainer UPT DLH Kabupaten Bantul sebagai narasumber dan 13 perwakilan ketua RPS yang tersebar di 12 Kecamatan yang berada di Kabupaten Bantul. Tujuan dari pelatihan dan workshop ini adalah untuk percepatan pemanfaatan mesin pencacah sebagai alat pengolah sampah organik. Selain itu, kegiatan ini bertujuan untuk menambah keterampilan pengurus RPS sehingga mampu menerapkan pengolahan sampah organik menjadi pupuk kompos. Adanya pelatihan dan workshop ini 
meningkatkan motivasi para kader RPS untuk mengelola sampah organik dan memanfaatkan seluruh hibah sarana prasana pengelola sampah dari DLH.

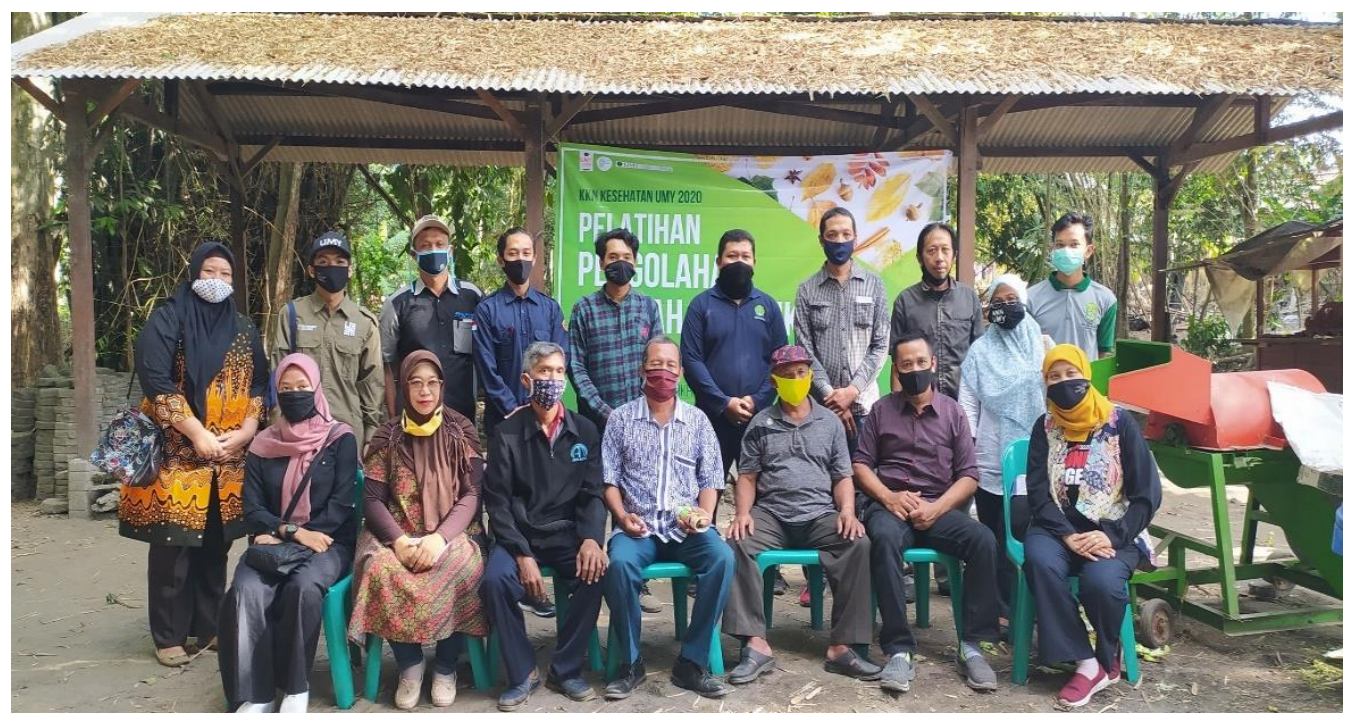

Gambar 3. Pelatiahan dan workshop pengelolaan sampah

5) Pendampingan administrasi dan pembukuan dilaksanakan pada tanggal 12 Agustus 2020 di rumah Bapak Riyo Sujono. Kegiatan dilaksanakan dengan protokol COVID-19 sehingga hanya dihadiri oleh dua orang perwakilan warga yaitu Bapak Riyo Sujono sebagai kader kelembagaan pilah sampah dan Bapak Dukuh sebagai tokoh masyarakat. Dalam kegiatan pendampingan ini diberikan materi berupa teknis administrasi dan pembukuan kelembagaan pilah sampah dengan konsep sedekah sampah. Materi yang diberikan meliputi administrasi Buku Besar Sedekah Sampah yang merupakan alat untuk macatat atau merekap hasil transaksi keuangan penjualan pilah sampah dan meteri administrasi Arus Kas Sedekah Sampah yang merupakan alat untuk mencatat laporan keuangan mengenai pemasukan dan pengeluaran kas kelembagaan dalam periode tertentu. Selain itu dalam kegiatan pendampingan ini juga diberikan hibah berupa Buku Saku yang didalamya terdapat materi dan tata cara/kerja terkait standar operasional kegiatan pilah sampah. Kegiatan pendampingan juga dilaksanakan secara daring (online) dengan menggunakan media elektronik ataupun media digital.

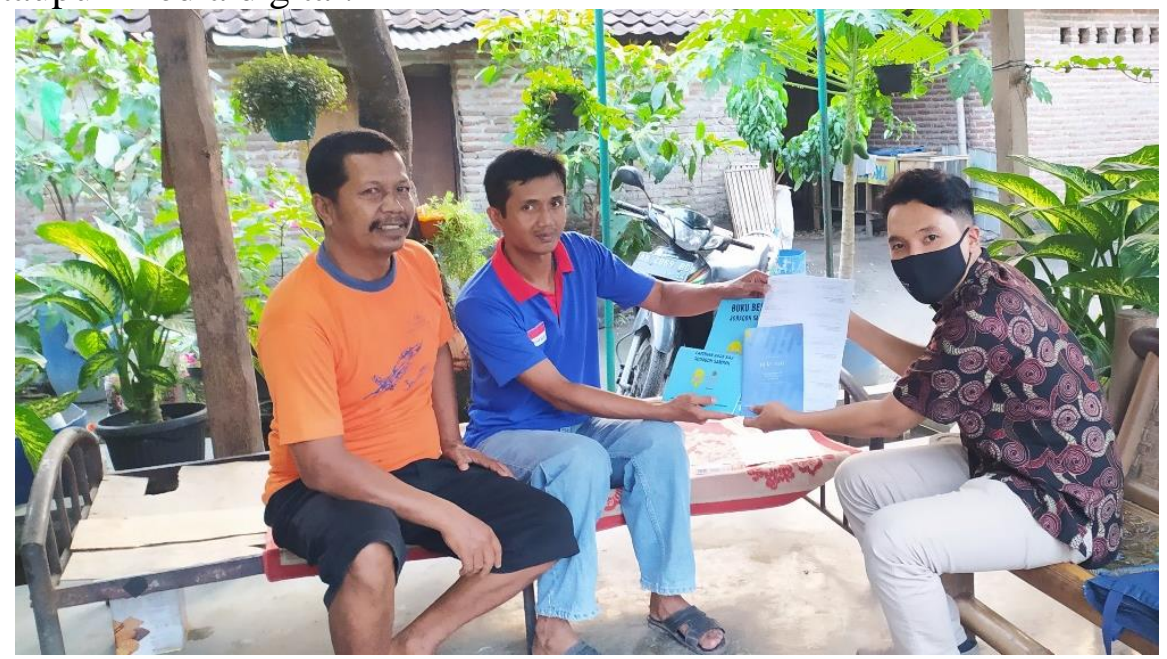

Gambar 4. Pendampingan administrasi dan pembukuan kelembagaan pilah sampah

6) Hibah operasional merupakan bentuk bantuan dana untuk kegiatan pengelolaan kelembagaan pilah sampah. Penyerahan hibah operasional dilaksanakan pada tanggal 18 September 2020 di Dusun Banjardadap tepatnya di rumah Bapak Riyo Sujono. Kegiatan dihadiri oleh tim 
pengabdian UMY beserta perwakilan kader kelompok RPS Ngudi Resik Barokah. Hibah berupa uang tunai sebesar Rp 1.000.000 dan sejumlah sapu tangan. Tujuan dari penyerahan hibah operasional yaitu untuk menunjang sarana dan prasarana kelembagaan pilah sampah yang masih belum memadai. Selain itu, manfaat hibah yaitu untuk memberikan motivasi kepada penggurus RPS agar tetap berkomitmen dalam mengelola kelembagaan pilah sampah, serta dalam hal ini pengurus juga menandatangani surat pernyataan komitmen bahwa akan melaksanakan kegiatan pengelolaan sampah dengan memanfaatkan seluruh sarana dan prasana yang ada.

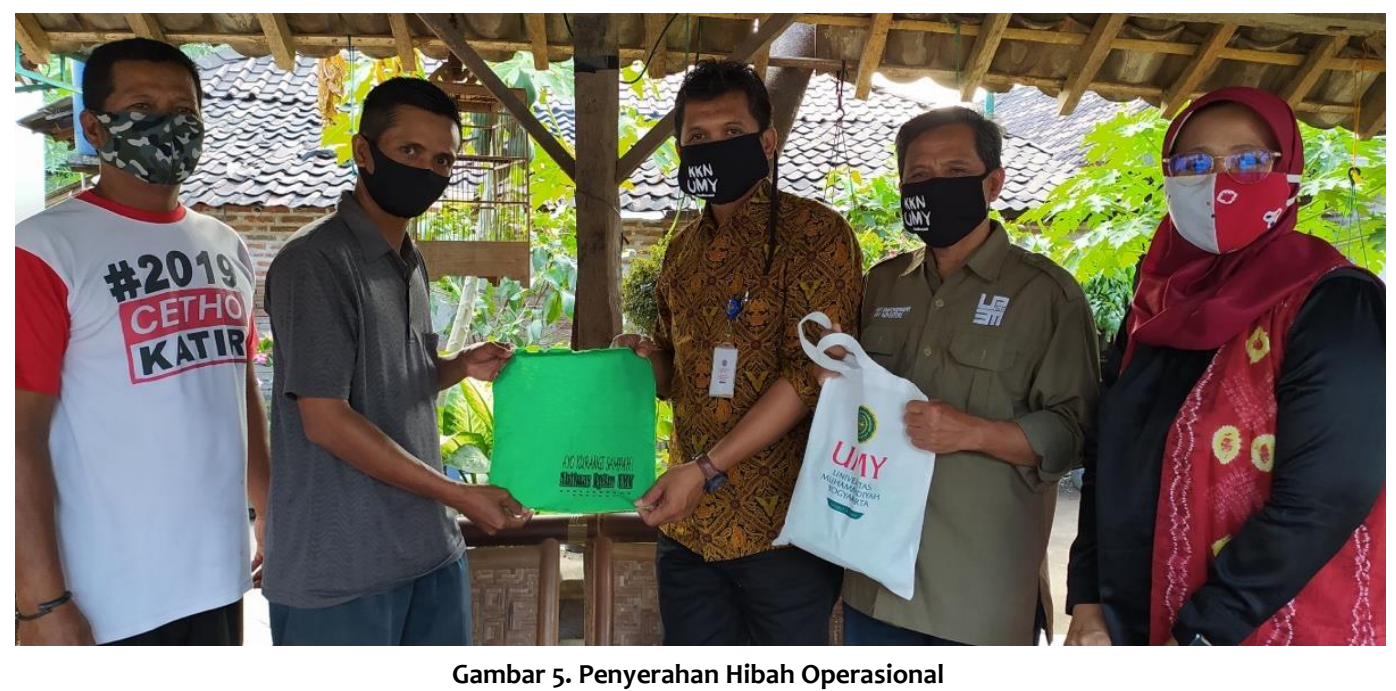

\section{Simpulan}

Program pengabdian Pendampingan Pilah Sampah Mandiri di Kelompok Pengelola Sampah Ngudi Resik (Pedukuhan Banjardadap, Desa Potorono, Kecamatan Banguntapan, Kabupaten Bantul) dilaksanakan selama 3 (tiga) bulan. Hasil pelaksanaan dalam program tersebut adalah sebagai berikut:

1. Sosialisasi telah dilaksanakan dan masyarakat telah mendapatkan informasi atau gambaran yang utuh terkait pentingnya pengelolaan sampah dan masyarakat termotivasi untuk melakukan pengelolaan sampah dengan membentuk kelembagaan pilah sampah.

2. Pelatihan dan workshop telah dilaksanakan dan berhasil meningkatkan keterampilan pengurus RPS dalam pemanfaatan alat pengolahan sampah organik menjadi pupuk kompos.

3. Pendampingan administrasi dan pembukuan kelembagaan pilah sampah telah berhasil untuk menambah keterampilan pengurus dalam pencatatan kelembagaan.

4. Penyerahan hibah operasional telah mampu meningkatkan motivasi pengurus dalam pengelolaan sampah mandiri dan pemanfaatan RPS dan akan digunakan untuk menunjang sarana dan prasarana kelembagaan pilah sampah yang masih belum memadai.

\section{Ucapan Terimakasih:}

1. Kelompok Pengelola sampah Ngudiresik

2. Kadus, Pedukuhan Banjardadap, Desa Potorono,

3. Lembaga Penelitian, Publikasi dan Pengabdian Masyarakat, Universitas Muhammadiyah Yogyakarta. 


\section{Daftar Pustaka}

Koeswantono W.S. 2017. Pemberdayaan Masyarakat Melalui Pelatihan Menyulam pada Ibu-Ibu di Desa Pabuaran Kecamatan Sukamakmur, Kabupaten Bogor. Jurnal Sarwahita Volume 11 No. 2.

Soetomo, 2012. Keswadayaan Masyarakat Manivestasi Kapasitas Masyarakat untuk Berkembang Secara Mandiri. Yogyakarta: pustaka pelajar.

Suharto, Edi. 2010. membangun masyarakat memberdayakan rakyat, bandung:Refika Aditama, 2010.

Suparjan \& Hempri Suyatno. (2003). Pengembangan Masyarakat dari pembangunan Sampai Pemberdayaan. Yogyakarta: Aditya Media.

Susanto dan Muhamad Iqbal, 2019. Pengabdian Kepada Masyarakat Dalam Sinergitas Akademisi

Dan

TNI

Bersama Tangkal Hoax Dan Black Campaign. CARADDE: Jurnal Pengabdian Kepada Masyarakat

https://journal.ilininstitute.com/index.php/caradde Volume 2 | Nomor 1 | Agustus |2019 e-ISSN: 2621-7910 dan p-ISSN: 2621-7961 DOI: https://doi.org/10.31960/caradde.v2i1.119.

Sururi A. 2017. Pemberdayaan Masyarakat Melalui Program Pembangunan Infrastruktur Perdesaan dalam Meningkatan Kesejahteraan Masyarakat Kecamatan Wanasalam, Kabupaten Lebak. Jurnal Administrasi Negara, Volume 3, Nomor 2, Jan - April,

Widodo, A.S., 2019. Teknik Fasilitasi Pemberdayaan Masyarakat. UMY Press, Lembaga Penelitian, Publikasi dan Pengabdian Masyarakat, Universitas Muhammadiyah Yogyakarta.

Widiastuti, Siti Kurnia, dkk. 2015. Pemberdayaan Masyarakat Marginal. Yogyakarta: Pustaka Pelajar.

Winarni T, 1998; Memahami Pemberdyaan Masyarakat Desa Partisipatif dalam Orientasi Pembangunan Masyarakat Desa menyongsong abad 21: menuju Pemberdayaan Pelayanan Masyarakat. Yogyakarta. Aditya Media. 